\title{
Celestine Bassey and Oshita Oshita (eds). 2007. Conflict Resolution, Identity Crisis and Development in Africa. Lagos: Malthouse Press Limited. 275pp.
}

\author{
Egbe, Olawari D.J \\ odjegbe@gmail.com
}

The end of the Cold War is often asserted to have left behind in its withering path a myriad of conflicts globally, though contrary scholarship exists (see Fearon and Laitin, 2003:88). Africa was not only worst hit; it was "at war with itself, with war-torn polities and pauperized and divided societies" (Adebayo, 1999) but also arguably came first in the conflict trend (Zartman, 1996; Adebayo, 2010). Worried by such an ugly trend in Africa, the Institute for Peace and Conflict Resolution (IPCR), Abuja, Nigeria, courageously consults with practitioners in conflict management and prevention in ending conflicts in Africa. This edited compendium, organized into three parts with unequal chapters, represents one of IPCR's numerous peace efforts in Africa.

The centrality of the text is the assertion that conflict/development crisis in Africa" is not ethnic hatred as erroneously conceived but economic and political institutional failures that manifest in poverty, bad governance; the totality of which adversely affect development in Africa (Ake, 1996). In thematic overview of conflict resolution, I. O. Albert and J.M. Amoda's chapters were simply parallel in syntax. In presenting peace and conflict studies as everyone's domain; one that is interested in "anything" and not necessarily the elimination of war alone, I. 0. Albert's Chapter One, "Concepts and Methods in Peace and Conflict Studies" is not only pedagogic but also rendered in a free flowing prose. It explains and clarifies concepts, methods of peace and conflict studies and how to become an expert in peace and conflict studies. J.M. Amoda's Chapter Two "Methodological Issues in Peace and Conflict Studies" presented in complex language asserted that peace and conflict studies in divided societies can best be studied as a form of sovereignty/contentious politics, defined as "contestations over sovereignty". Thus, in classifying conflicts in Africa into state security, state creation, state development, state expansion, and country creation and country state formation politics, Amoda see the last category as most relevant to Africa and indeed Nigeria, where sovereignty is instituted by way of coercion.

International politics is premised on state sovereignty and non-intervention but states oftentimes terrorize their citizens (Stohl and Lopez, 1984 eds). Thus, when can a humanitarian intervention be made? In Chapter Three, "Humanitarian Intervention and Protracted Social Conflict", Joseph P. Ochogwu, dwell on this hotly debated subject (see Evans, 2006; Bolton, 2008)). Indeed legal (Benjamin, 1992:157), moral (Pattison, 2010:26) and political (Ezeabasili, 2011:17) issues bedevil humanitarian intervention vis-à-vis state sovereignty. But of what value is state sovereignty without responsibility; for

state sovereignty implies responsibility, and the primary responsibility for the protection of its people lies with the state itself... Where a population is suffering serious harm, as a result of internal war, insurgency, repression or state failure, and 
the state in question is unwilling or unable to halt or avert it, the principle of nonintervention yields to the international responsibility to protect" (ICISS, 2001: xi).

J.P. Ochogwu advised that to save humanity from the scourges of war, humanitarian interventions that are devoid of a discriminatory response can be made. But who should authorize a humanitarian intervention; the Security Council, the recently muted concept of Responsibility to Protect (R2P) or a unilateral approach by a world power? Moreover, these institutions/world powers are often accused of being biased and pursuing their realist interests (Ezeabasili, 2011:17). While some scholars are advocating for a council of judges (see Teson, 2006), others are calling for "strengthening parts of the system that are promising: existing legal instruments and institutions that fulfill many of the functions of R2P without undermining the principles of peaceful dispute settlement and of the equal sovereignty of states" (Pingeot and Obenland 2014:47).

A careful handling of linguistic issues is a sure way to conflict resolution (see Bush and Saltarelli, 2000:17; Krauss and Morsella, 2000; Adejimola, 2009). While E. M. Iji's "Language and Communication in Peace and Conflict Resolution (chapter 4)" solicited for caution in language in conflict resolution no matter the justification; J.E. Gyong's chapter 5, "The Structure of Communication in Peace and Conflict Resolution" annunciated the ideals of language; especially tolerance as a criterion for peaceful co-existence.

Ottaway (in Ganahl, 2013:158) notes that in the absence of ideological and programmatic differences, ethnicity remains "the major characteristic by which the various parties could differentiate themselves". Part 11 of the text, christened "Identity Crisis" begins with Okwudiba Nnoli's chapter 6: "Theories and Concepts of Ethnicity". Ethnicity in Africa is considered resulting from the use of state power by "those who control the state". Thus, conflict is eminent as the different ethnic groups struggle to control the state apparatus. Conflict management in such states is difficult as the state is not only an interested party but also one that manages conflict by suppression. Nnoli recommends democratization among African states by way of decentralizing social power in the society and in turn empower institutions as civil society organizations, the mass media, etc, in the prevention, management and resolution of conflict. Though the chapter is comprehensive, exhaustive, sparing use of direct quotes and most elaborate in its end-of-chapter references vis-à-vis other chapters in the text, decentralization as a means of conflict resolution has received much criticism (Brancati, 2006:651).

In Chapter 7: "Power Sharing, Political Stability and Ethnicity in Africa", Samuel Egwu proposed consociationalism within the confines of democracy to deal with the peculiarities of Nigeria's ethnic and divisive character; but Arend Lijphart's consociationalism as a model has its fair share of criticisms. Consociationalism's foremost critic, Brian Barry (1975) argued that "the model of 'consociational democracy' is no longer regarded...as a curiosity but may be in danger of being accepted too uncritically as a model for the resolution of divisions within a society...to suggest that the effect of attempting to introduce consociational practices might make matters worse". van Schendelen, (1984) posited that,

The crucial elements of consociationalism have not been operationalized by Lijphart; that more specifically, the main concepts are loosely formulated (not to mention the minor concepts), that they are often based on implicit theoretical thinking, sometimes badly adapted to the complexities of the plural society to be studied, and that their indicators, in so far as they are mentioned, are often just as loosely formulated, theoretically biased, and not accurate measures of the complexities in consociational 
politics (p.160). Thus, Lijphart's consociationalism lacks scientific qualities of validity, verifiability, predictive power, and applicative potential and at best 'consociational democracy remains elitist democracy" (p.173)

From an African perspective, Lemarchand (2007) argued that "translating consociational theory into practice has generally failed in much of Africa". It is rather suggested here that arising from the apparent constraints in the applicability of consociationalism in African societies, diverse constitutional measures such as "gradual constitutional reform to strengthen liberal institutions, such as strong judiciaries and independent electoral commissions", could be adopted to achieve stability but definitely "not only by accommodative institutions that encourage decentralization and multiculturalism" (Kuperman, 2014).

The authors in "Chapter 8: Conflict, Equity and Resource Capture in Africa: The Nigerian Experience", explored the Niger Delta (hereafter ND) development paradox in Nigeria; suggested a number of palliatives if implemented could settle the crisis in the region, etc. Aside the chapter being very brief on an issue with a burgeoning literature, two questions are pertinent here. First, who authored the chapter? Though it is written as being co-authored (Bob Osaze \&Oshita Oshita) it is otherwise stated as being single authored with use of a personal pronoun I and not we (p.112). Secondly, Odi community in Bayelsa state is not an oil bearing community (pp.114, 246).

Judith Burdin Asuni's "Chapter 9: Culture and Conflict", brought to bear her wealth of practical/field experience in conflict prevention, management and resolution asserting that peace reigns where groups learn to accommodate their differences. However, conflict always stirs group differences where a group tends to impose superiority over other groups. She recommends a third party with vast knowledge of both cultures to broker peace between/among the conflicting ethnic groups. But are third party mediators equipped with the challenges such roles presents; for it is a,

Reality that any intervention process activates resistance and, when it is not handled effectively, it can be a disruptive source of discomfort for mediators...Feelings of frustration, sense of failure, hopelessness, anxiety, resentment, loss of energy, insecurity, fatigue can result...the key to handling resistance is feeling secure with the mediation process. The hope would be that mediators, recognizing the significance of resistance to their work, would continue to learn more about its manifold roots and conceptualization, and work to develop better ways of recognizing and dealing with it (Volpe and Bahn, 1992:36).

D.A. Guobadi writing on "Ethnicity, Gender and Peace" in chapter 10 highlighted ethnicity and gender as elements that bear the germ with the ability to threaten the peace of states. But ethnicity and gender are not entirely on the negative spectrum (Rothchild, 1997: vii). The author while relying on the provisions of Section 15 (1-4) of the 1999 Nigerian Constitution as a conflict management strategy should not be oblivious of the endemic Nigerian insincerity in matching theory to practice in her constitutional provisions.

In "Chapter 11: Epidemiology of Conflict and Violence in Nigeria", Celestine Bassey traced the prevalence of conflict in Nigeria to amongst others its "formative years", "process of societal transformation", "system contradictions", and "poor governance". To resolve Nigeria's numerous conflicts, the author recommends the empowering of non-state actors as NGOs, CBOs. But can NGOs be entrusted with conflict management? There is a burgeoning scholarship 
that points otherwise (Fatton, 1995:93; Ikelegbe, 2001; World Bank, 2005; O'Connor, 2012) to the colossal lapses of NGOs/CBOs in conflict resolution that have been overlooked for too long. Little wonder Anderson (1996) cautioned that,

\begin{abstract}
By failing to consider the political implications of their work, NGOs have in many cases exacerbated the very conflicts and violence they were seeking to relieve. NGO bring new resources into a conflict situation...NGO actions and attitudes can also exacerbate conflict. The author notes, "NGOs must choose to employ some people (and not others), purchase goods from some (and not others), and target their aid toward some people (and not others); these decisions can fuel separate group identities, inequalities, and jealousies.
\end{abstract}

Part 111: "Conflict Resolution and Development in Africa", commenced with Mark Anikpo's "Chapter 12: Violence as a Feature of Inter-ethnic Compensations: Implication for Stability and Development". Written in a free-flowing prose the author with specific case studies identified imbalance in resource allocation and distribution as the catalyst to inter-ethnic violent conflicts and especially a bane to Nigeria's economic, political and social development. He recommends amongst others assuaging aggrieved ethnic groups, provision of employment opportunities, battling the scourge of poverty, etc, as conflict management and prevention strategies.

Chapters 13 (Federalism and the Management of Ethnicity in Nigeria: 1999 Constitution in Focus) and 14 (Ethnicity, Political Stability and Economic Development in Africa") advocated for the adoption of federal constitution in managing ethnic conflict in divided societies. As E.E. Osaghae noted federalism's greatest fallacy lies in matching theory with practice (see Rothchild, 1966; Anderson, 2013). For Ayo Dumoye overcoming Africa's poor economies resulting from ethnic conflicts could be managed aside federal constitution, the empowering of NGOs, and the enforcement of the moratorium on the importation, exportation and manufacture of light weapons/arms as mediums for preventing conflict. From the foregoing, three issues are pertinent here: (a) as earlier observed NGOs are seen as interested parties, and (b) to the extent that war remains a racket, (see Butler, 1935) the moratorium on the importation, exportation and manufacture of light weapons/arms is simply a ruse.

The paradox of development and its resultant conflict in the ND was the subject-matter in chapters 15 and 16. Using the Urhobo Ethnic Nationality as a case study, Peter B. Okoh, in "Chapter 15, The Place of Ethnicity in the Struggle for Self-determination of the South-South Zone of Nigeria", restated the paradox of development in the ND and its conflict precipitating tendencies. Though an interesting chapter, highlights from the chapter indicates that it was written before 1996, but published in 2007; that is a ten year difference. Therefore, the chapter did not discuss developments in the ND from 1996-2007. For example, the chapter dwelled on the OMPADEC and not the NDDC (1999) as the development agency; the author referred to five oil producing states without a mention of Bayelsa state (created in 1996) as one (p.241). Furthermore, it is the longest chapter (38 pp) but with the least references on a subject as the ND self-determination struggle where an avalanche literature exist.

Greed vs. grievance debate in the ND self-determination struggle preoccupied Oshita O. Oshita in "Chapter 16: Resources and Conflict: A Case Analysis of Niger Delta". He saw the struggle as grievance precipitated rather than greed. Though an interesting chapter, much is yet to be seen from the three key recommendations proffered to assuage the restiveness in the ND: (a) the NDDC since its incorporation in 1999 as a government intervention agency in the ND has 
received thunderous outcries against her activities, especially her slow pace, government poor funding, etc; (Etekpe, 2009), (b) Civil Society Organizations (CSOs) involvement in implementing the Shell GMoU in the Gbarain/Ubie Liquefied Natural Gas (LNG) gathering project (in Bayelsa State) is fraught with allegations of CSOs working too closely with Shell rather than the communities they are supposed to serve; and (c) international support from World Bank and its sister organizations is a suspect, as they are rather partners in an unholy connivance with oil TNCs in various ecological and social malaises in resource-rich regions in the world, especially where "their operations have demonstrated the environmental blindness of much of post-war economic theory which assumes that the market maximizes social welfare and generally produces socially desirable levels of consumption of natural resources" (Thomas, 1992:65).

While the conclusion of the text provided practical steps in conflict resolution, a major weakness in the text is the mix-up in referencing. Works cited in most chapters are not referenced; whereas works not cited at all are instead reflected. Additionally, despite the highlighted weaknesses, this compendium made a huge contribution to the overwhelming literature on conflict resolution that is both accessible and a good read.

\section{References}

Adebayo, A (1999, ed) Comprehending and Mastering African Conflicts: The Search for Sustainable Peace and Good Governance. London and New York: Zed Books,

Adebayo, A (2010) The Curse of Berlin: Africa After the Cold War. London: Hurst

Adejimola, A.S (2009): Language and Communication in Conflict Resolution. Journal of Law and Conflict Resolution 1(1), 001-009

Ake, C (1996): Democracy and Development in Africa. Washington: Brookings Institute.

Anderson, L. D (2013) Federal Solutions to Ethnic Problems: Accommodating Diversity. New York: Routledge,

Anderson, M (1996): "Humanitarian NGOs in Conflict Intervention," In Chester Crocker, Fen Hampson and Pamela Aall, eds. Managing Global Chaos. Washington, D.C.: United States Institute of Peace Press, pp. 343-354,

Barry, B (1975): The Consociational model and its dangers. European Journal of Political Research, 3(4), 393-412,

Benjamin, B.M (1992) Unilateral Humanitarian Intervention: Legalizing the Use of Force to Prevent Human Rights Atrocities. Fordham International Law Journal 16 (1): 120-158

Bolton, J.R (2008): The Case against Humanitarian Intervention

Brancati, D (2006) Decentralization: Fueling the Fire or Dampening the Flames of Ethnic Conflict and Secessionism? International Organization 60 (3): 651-685,

Bush, K.D and D. Saltarelli (2000 eds) The Two Faces of Education in Ethnic Conflict: Towards a Peace-building Education for Children. Italy: UNICEF,

Butler, S (1935): War is a Racket. USA: Round Table Press,

Etekpe, A (2009) The Niger Delta Development Commission (NDDC) and Peace-Building in the Niger Delta.

National Development Review 1, 2-78,

Evans, G (2006) From Humanitarian Intervention to the Responsibility to Protect. Keynote Address by Gareth Evans, President of International Crisis Group and Co-Chair of the International Commission on Intervention and State Sovereignty 2001, to Symposium on Humanitarian Intervention, University of Wisconsin, Madison, 31 March 2006.

Ezeabasili E. I (2011), Humanitarian Intervention in Africa: A Re-Visit of the Darfur Conflict. Global Journal of Human Social Science, 11 (8): 11-18,

Fatton, R (1995) Africa in the Age of Democratization: The Civic Limitations of Civil Society. African Studies Review, 38 (2): 67-99, 
Fearon, J.D and D. D. Laitin (2003): Ethnicity, Insurgency, and Civil War. American Political Science Review 97 (1): 75-90,

Ganahl, J.P (2013) Corruption, Good Governance, and the African State: A Critical Analysis of the PoliticalEconomic Foundations of Corruption in Sub-Saharan Africa. Potsdam: Potsdam University Press,

Ikelegbe, A (2001) The Perverse Manifestation of Civil Society: Evidence from Nigeria. The Journal of Modern African Studies, 39 (1): 1-24,

Int'l Commission on Intervention and State Sovereignty (ICISS, 2001) The Responsibility to Protect. Canada: Int'l Development Research Centre,

Krauss, R.M and E. Morsella (2000) “Communication and Conflict”, In M. Deutsch and P. Coleman, (eds.) The Handbook of Constructive Conflict Resolution: Theory and Practice. San Francisco: Jossey-Bass, pp.131-143

Kuperman, A.J (2014) Constitutions and Conflict Management in Africa: Preventing Civil War through Institutional Design,

Lemarchand, R (2007) Consociationalism and Power Sharing in Africa: Rwanda, Burundi, and the Democratic Republic of the Congo. African Affairs, 106 (422), 1-20

O'Connor, J. (2012) 'NGO': The Guise of Innocence. Irish Foreign Affairs, 5 (1), 5-8,

Pattison, J (2010): Outsourcing the Responsibility to Protect: Humanitarian Intervention and Private Military and Security Companies. International Theory, 2 (1): 1-31

Pingeot, L and Wolfgang Obenland (2014) In Whose Name: A critical view on the Responsibility to Protect. Germany: Global Policy Forum,

Rothchild, D (1966): The Limits of Federalism: An Examination of Political Institutional Transfer in Africa. The Journal of Modern African Studies, 4(3), 275-293,

Rothchild, D (1997) Managing Ethnic Conflict in Africa: Pressures and Incentives for Cooperation. Washington, DC: Brookings Institution,

Stohl and Lopez, (1984, eds) The State as Terrorist: The Dynamics of Governmental Violence and Repression. Connecticut: Greenwood Press,

Teson, F.R (2006): The Vexing Problem of Authority in Humanitarian Intervention: A Proposal. Wisconsin International Law Journal 24(3), 761-772

Thomas, C (1992): The Environment in International Relations. London: Royal Institute of International Affairs, van Schendelen, M.C.P.M (1984) Consociational Democracy: The Views of Arend Lijphart and Collected Criticisms. Acta Politica, 9(1), 19-49,

Volpe, M. R. and Bahn, C (1992) Resistance to Mediation: Understanding and Handling It. Sociological Practice: 10 (1), 26-37),

World Bank (2005) Engaging Civil Society Organizations in Conflict Affected and Fragile States: Three African Country Case Studies. Report No. 32538-GLB.

Zartman, W. I (1996) Governance as Conflict Management: Politics and Violence in West Africa. Brookings Institution Press 